Doi: HTTPS://DOI.ORG/10.23910/2/2021.0421

\title{
Status of Sandalwood (Santalum album Linn.) in Low Hills of Himachal Pradesh
}

\author{
Som Dutt ${ }^{1}$, Kamal Sharma ${ }^{1}$, Vivek Sharma ${ }^{1}$ and Varun Dhiman ${ }^{2}$ \\ ${ }^{1}$ College of Horticulture and Forestry Neri, Hamirpur, Dr. Y. S. Parmar University of Horticulture and Forestry, Nauni, Solan, \\ Himachal Pradesh (177 001), India \\ ${ }^{2}$ Dept. of Environmental Science, Central University of Himachal Pradesh, Dharamshala, Himachal Pradesh (176 215), India
}

\section{Corresponding Author}

Som Dutt

e-mail: sdsharma15366@gmail.com

\section{Article History}

Article ID: IJEP0421

Received on $06^{\text {th }}$ May, 2021

Received in revised form on $30^{\text {th }}$ October, 2021

Accepted in final form on $12^{\text {th }}$ November, 2021

\begin{abstract}
The present investigation on the status of Sandalwood (Santalum album Linn.) in low hills of Himachal Pradesh was carried out in the Department of Silviculture and Agroforestry in the laboratory at the main campus of the Dr. Y. S. Parmar University of Horticulture and Forestry, Nauni, Solan and in the field at Bilaspur and Jawala Mukhi varying in altitude from $500-850 \mathrm{~m}$. The growth behavior of sandals was studied through the selection of 10 ha sampling plot at Bilaspur and 5 ha sampling plot at Jawala Mukhi based on tree density. The investigations revealed that the trees have covered an area of 15 ha at Bilaspur and 30 ha at Jawala Mukhi. The total number of trees growing at Bilaspur and Jawala Mukhi was found to be 1076 and 815, respectively. Further, average oil content was about 3.86 and $3.90 \%$ in the heartwood of S. album growing at Bilaspur and Jawala Mukhi. Phytosociological parameters of vegetation in sandal stand at Bilaspur revealed Santalum album as the dominant tree species with its maximum IVI value which corresponds to its higher frequency, basal area, and density.
\end{abstract}

Keywords: Basal area, essential oil, host, importance value index

\section{Introduction}

The Sandal (Santalum album Linn.) is one of the most important commercial tree species of India (Sandeep and Manohara, 2019). It is called the 'Royal tree' because its distribution is restricted, its oil is unique and of high value and the santalol in the sandalwood makes the wood impenetrable by termites (Sundararaj et al., 2019). It is commonly known as East Indian sandalwood or Chandana, belonging to the family Santalaceae (Sandeep et al., 2020). It is valuable for its fragrant heartwood (Tah, 2021). It is an evergreen tree attaining a height of 12 to $15 \mathrm{~m}$ and girth of 1 to $2.4 \mathrm{~m}$ with slender, dropping as well as erect branching (Chitra and Jijeesh, 2021). It flowers and fruits twice a year during MarchApril and September-October (Rao and Bapat, 1992) which are purplish-brown in color while the fruit is a drupe, purple brown when fully ripe and is single-seeded (Roy et al., 2017). The Sandal tree is a rare marvel of ecology, springing up in a forest where it was never seen before. It happily coexists with all kinds of other plants. Its roots entwine with the roots of other plants in the soil presents a complex system of coexistence. However, it does not harm the host plant. But when man tries to force it to grow in large numbers, it gradually disappears (Anonymous, 1997). It is a semi root parasite species. Its parasitic nature was first time reported by Scot in 1871 (Da
Silva et al., 2016). It can parasitize over 300 species from grass to another sandal plant. Under gregarious growing conditions, self-parasitism is common (Doddabasawa and Chittapur, 2021). Its host during its nursery stage is different than in its plantation stage. Cajanus cajan and Casuarina equisitifolia proved to be their best host during nursery and plantation stages, respectively (Rocha et al., 2014). It is economically very important as it provides fragrant heartwood. Besides its vital importance on the economic ground, it is one of the ingredients of Indian culture and heritage. It has been used as an object in ritualistic offerings, and also an ointment for beauty. Its heartwood is closely grained and thus found to be the best wood for carving purposes such as the carving of idols, cabinet panels, chess boards, pen-holders, paperweights and picture frames (Nurochman et al., 2019). It is distributed between $30^{\circ} \mathrm{N}$ and $40^{\circ} \mathrm{S}$ from Indonesia in the West to Juan Fernadez Islands in the East and from Hawaiian Archipelago in the North to New Zealand in the South (Srinivasan et al, 1992). It is further reported that in India, Sandal is found distributed all over the country and more than $90 \%$ lies in Karnataka

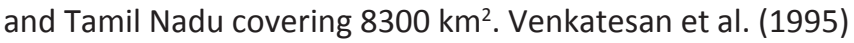
reported a state-wise assessment of sandal in India. They reported that sandal is distributed in $9040 \mathrm{~km}^{2}$ area in India. In Karnataka, Tamil Nadu, Andhra Pradesh, Madhya Pradesh and Maharashtra, sandal trees are distributed over an area of 
$5245,3045,175,33$, and $8 \mathrm{~km}^{2}$, respectively. Sandal trees are found growing in Kangra Valley near Jawala Mukhi of Himachal Pradesh. The area is about 30 to 35 ha. This contains nearly 4000 trees some of which are stated to be 30-35 years old.

Sandalwood on steam distillation yields an essential oil known as 'East Indian Sandalwood Oil' (Tah, 2021). Essential oils are complex compounds or mixtures of odorous and steam volatile nature. They are deposited in the plants in the cell organelle, in the heartwood, excretory cavities and canals. It is also known as "Liquid Gold" (Xiao et al., 2021). The oil contains $90 \%$ santalol, $25.5-5.0 \%$ santalyl acetate and 1.5-3.0\% santalenes.

Knowing its economic and cultural importance, people in the past made some attempts to introduce sandalwood in northern India. The existence of sandalwood at Jawala Mukhi and Bilaspur which falls in the sub-tropical sub-mountain low hill zone (up to $900 \mathrm{~m}$ amsl) of Himachal Pradesh is the result of such an introduction. An army officer during World War II, for the first time, planted some trees of sandalwood at Jawala Mukhi (District Kangra) in the late forties. Later on, sandal trees got naturalized but could not spread beyond these sites. However, the entire sub-tropical sub-mountain hill zone covering an area of $9130.37 \mathrm{~km}^{2}$ suits well to the soil and climate requirements of the species. Therefore, the present study was undertaken to study the status of Sandalwood in the low hills of Himachal Pradesh.

\section{Materials and Methods}

The present investigation was undertaken in the Department of Silviculture and Agroforestry, Dr. Y.S. Parmar University of Horticulture and Forestry, Nauni (Solan), Himachal Pradesh.

\subsection{Experimental sites}

\subsubsection{Location}

Laboratory studies were conducted at Nauni located at $30^{\prime \prime} 51^{\prime} \mathrm{N}$ latitude and $76^{\circ} 11^{\prime} \mathrm{E}$ longitude, at $1200 \mathrm{~m}$ amsl. Field and nursery experiments were conducted at Jawala Mukhi and Bilaspur varying in altitude from $500-850 \mathrm{~m}$ amsl.

\subsubsection{Climate}

Nauni falls under subtropical to sub temperate climate with an average annual rainfall of about $1250 \mathrm{~mm}$. Generally, May and June are the hottest months and December to February is the coldest. Bilaspur and Jawala Mukhi are in the subtropical sub-mountain low hill zone. The soils of the field sites are shallow, light-textured and loamy sand to sandy loam. The $\mathrm{pH}$ of the soils varies from 6.5 to 8 .

\subsection{Status of Sandalwood}

\subsubsection{Population dynamics}

The general growth behavior of sandalwood occurring in Himachal Pradesh was studied through a selection of 10 ha sampling plot at Bilaspur and 5 ha at Jawala Mukhi. The selection of the site was based on tree density. The trees were marked with white paint. Instruments used to study the population dynamics were metal caliper, vernier caliper, measuring tape and Spiegel Relaskop. Observation recorded were as follows:

a. Number of trees at each site: Total number of sandal trees grown at Bilaspur and Jawala Mukhi were enumerated and numbered with white paint.

b. Diameter of the trees: Diameters of all the marked sandal trees having diameters not less than $5 \mathrm{~cm}$ at breast height were recorded in $\mathrm{cm}$ with the help of a metal caliper.

c. Height of the trees: The height of all the marked trees having diameters not less than $5 \mathrm{~cm}$ were recorded in meters with the help of Spiegel Relaskop.

d. Number of trees in different diameter classes: The marked trees including saplings below five $\mathrm{cm}$ (including the nearby regenerated recruits) were classified based on diameter classes. The diameter classes were made as:

\begin{tabular}{lc}
\hline Diameter Class & Diameter $(\mathrm{cm})$ \\
\hline 1 & $<5 \mathrm{~cm}$ \\
2 & $5-10 \mathrm{~cm}$ \\
3 & $10-15 \mathrm{~cm}$ \\
4 & $15-20 \mathrm{~cm}$ \\
5 & $20-25 \mathrm{~cm}$ \\
\hline
\end{tabular}

\subsection{Phytosociological analysis of vegetation}

At each site, five quadrates each of $10 \times 10 \mathrm{~m}^{2}$ i.e., $100 \mathrm{~m}^{2}$ for trees and shrubs, and five quadrates of $1 \times 1 \mathrm{~m}^{2}$ i.e., $1 \mathrm{~m}^{2}$ for herbaceous components were randomly laid out. Percent frequency, density, basal area, relative frequency, relative density, relative dominance, and importance value index were calculated for each species with the formula after the presentation by Mishra, 1968 as follows:

Per cent frequency=(Number of sampling units in which in which the species occurred/Total number of units studied) $\times 100$ Density $=$ (Total number of individuals of the species/total number of quadrates studied)

Basal area $=\pi r^{2}$

Where, $r=$ radius

Basal area was measured at $20 \mathrm{~cm}$ above ground level for all species

R.F. (Relative Frequency)=(Frequency of individual species/ Frequency of all species) $\times 100$

R.D. (Relative Density)=(Density of individual species/Total basal area of all species) $\times 100$

R.D (Relative Dominance)=(Total basal area of the species/ Total basal area of all species $) \times 100$

I.V.I (Importance Value Index)=Relative Frequency + Relative Density+Relative Dominance 


\subsection{Quality characteristics}

\subsubsection{Percentage of oil content}

To confirm the existence and determine the quantity of oil in the heartwood of sandal trees growing in Himachal Pradesh conditions, preliminary studies were conducted. The heartwood samples were taken from sandal trees growing at Bilaspur and Jawala Mukhi with the help of Pressler increment borer. For extraction studies, 4 samples of $10 \mathrm{gm}$ each of sandal heartwood were taken. These samples were dried and grounded to powder. The dried power of heartwood was soaked in water in a $1000 \mathrm{ml}$ round bottom flask for 48 hours and then distilled with water for 72 hours. Thereafter, the floating oil in the distillate was mechanically skimmed off and was further refined by filtration.

\subsection{Physical and chemical characteristics of soil}

To study the physical and chemical characteristics of soil, soil samples (0-30 cm depth) were collected from the natural sandal growing areas of Bilaspur and Jawala Mukhi. Soil samples were air-dried in shade. Crushed and sieved through a $2 \mathrm{~mm}$ sieve and stored in cloth bags for chemical analysis. Soil texture, soil $\mathrm{pH}$, organic carbon, available $\mathrm{N}, \mathrm{P}$ and $\mathrm{K}$ were determined. The methods used to determine these soil chemical properties are given below:

\begin{tabular}{|c|c|c|}
\hline $\begin{array}{l}\text { Sl. } \\
\text { No. }\end{array}$ & Parameter & Method \\
\hline 1. & Soil texture & $\begin{array}{l}\text { International pipette method } \\
\text { (Piper, 1966) }\end{array}$ \\
\hline 2. & Soil pH & $\begin{array}{l}\text { 1:2:5 soil: water suspension, } \\
\text { with the help of digital } \mathrm{pH} \\
\text { meter (Jackson, } 1973 \text { ) }\end{array}$ \\
\hline 3. & Organic carbon (\%) & $\begin{array}{l}\text { Vegetative method for } \\
\text { determining organic carbon } \\
\text { (Walkley and Black, 1934) }\end{array}$ \\
\hline 4. & $\begin{array}{l}\text { Available nitrogen } \\
\left(\mathrm{kg} \mathrm{ha}^{-1}\right)\end{array}$ & $\begin{array}{l}\text { Alkaline potassium perman- } \\
\text { ganate method (Subbiah and } \\
\text { Asija, 1956) }\end{array}$ \\
\hline 5. & $\begin{array}{l}\text { Available phospho- } \\
\text { rus }\left(\mathrm{kg} \mathrm{ha}^{-1}\right)\end{array}$ & $\begin{array}{l}\text { Estimation of available } \\
\text { phosphorus (Olsen et al., } \\
\text { 1954) }\end{array}$ \\
\hline 6. & $\begin{array}{l}\text { Available potassium } \\
\left(\mathrm{kg} \mathrm{ha}^{-1}\right)\end{array}$ & $\begin{array}{l}\text { Flame photometer analysis } \\
\text { (Merwin and Peech, 1951) }\end{array}$ \\
\hline
\end{tabular}

\subsection{Leaf chemical analysis}

Leaf chemical analysis was carried out to determine different leaf mineral nutrients content of Santalum album. The methodology followed is as below:

\subsection{Preparation of samples}

Leaf samples of Santalum album trees growing naturally at Bilaspur and Jwala Mukhi were brought and washed with tap water. The washed leaves were first air-dried in shade and subsequently in an oven at $60 \pm 5^{\circ} \mathrm{C}$ till constant weights were found and stored in butter paper bags for chemical analysis. For the estimation of total $\mathrm{N}, 0.02 \mathrm{gm}$ of plant sample was digested in $\mathrm{H}_{2} \mathrm{SO}_{4}$ using digestion mixture $\mathrm{K}_{2} \mathrm{SO}_{4}, \mathrm{CuSO}_{4}$ (3.5:0.4). After digestion $\mathrm{N}$ was estimated in Kjeltec auto 1030 Analyzer. For the estimation of total $P, K$, and $\mathrm{Ca}$, the wet digestion of plant samples was carried out in a Di-acid mixture consisting of Nitric acid and Perchloric acid in the ratio of 4:1. Ground sample of a plant weighing $0.5 \mathrm{~g}$ was digested with 10-15 $\mathrm{ml}$ of the di-acid mixture. To have a complete transfer of digested material, three piles of washing of digestion flask were given with distilled water and the final volume of the digestion was made to $100 \mathrm{ml}$. Phosphorous in the digested sample was determined by Vanado-molybdo phosphoric yellow color method using Spectronic 20-D, whereas, $\mathrm{K}$ and Ca were estimated flame photometrically.

\section{Results and Discussion}

Data on the status of Sandalwood in the low hills of Himachal Pradesh have been presented in Tables 1-5. Data in Table 1 indicates that Sandalwood was found distributed at two sites viz. Bilaspur (Site-I) and Jawala Mukhi (Site-II). The total number of trees at Site-I and Site-II were found to be 1076 and 815 , respectively. Maximum average height and diameter of trees at Site-I were found to be $15.50 \mathrm{~m}$ and $22.50 \mathrm{~cm}$., respectively. At Site-II, the values for these parameters were, however, recorded as $14.25 \mathrm{~m}$ and $20.25 \mathrm{~cm}$. At Site-I, the maximum number of trees (502) was found in diameter class $5-10 \mathrm{~cm}$ and minimum (3) in diameter class $20-25 \mathrm{~cm}$. Whereas, at Site-II maximum number of trees (386) were found in diameter class less than $5 \mathrm{~cm}$ and minimum (6) in diameter class $20-25 \mathrm{~cm}$. The heartwood oil content of trees was found to be 3.86 and $3.90 \%$ at Site-I and Site-II, respectively. It is comparable to the variations found in the

Table 1: Status of Sandalwood (Santalum album Linn.) in low hills of Himachal Pradesh

\begin{tabular}{llcc}
\hline $\begin{array}{l}\text { SI. } \\
\text { No. }\end{array}$ & Population dynamics & $\begin{array}{c}\text { Site-I } \\
\text { (Bilaspur) }\end{array}$ & $\begin{array}{c}\text { Site-II } \\
\text { (Jawala Mukhi) }\end{array}$ \\
\hline 1. & $\begin{array}{l}\text { Average maximum } \\
\text { height }(\mathrm{m})\end{array}$ & 15.50 & 14.25 \\
2. & $\begin{array}{l}\text { Average maximum } \\
\text { diameter }(\mathrm{cm})\end{array}$ & 22.50 & 20.25
\end{tabular}

3. Diameter Classes

No. of trees in different diameter classes

\begin{tabular}{|c|c|c|c|}
\hline & $<5 \mathrm{~cm}$ & 423 & 386 \\
\hline & $5-10 \mathrm{~cm}$ & 502 & 271 \\
\hline & $10-15 \mathrm{~cm}$ & 121 & 110 \\
\hline & $15-20 \mathrm{~cm}$ & 27 & 42 \\
\hline & $20-25 \mathrm{~cm}$ & 3 & 6 \\
\hline 4. & Total number of trees & 1076 & 815 \\
\hline 5. & Oil content (\%) & 3.86 & 3.90 \\
\hline
\end{tabular}


trees growing in south India, the natural home of sandalwood. The sampling area at Site-I and Site-II was determined based on the density of the sandalwood plantation (Table 1). At Site-I (Bilaspur), a 10 ha area was selected because of its dense stand at one particular place only. At Site-II (Jawala Mukhi), most plantations were found scattered adjoining to the town and farmers' agricultural landholdings. Due to these basic underlying characteristics of sandalwood plantation at Site-II, a patch of 5 ha area could only be selected. There has been no significant difference among the population dynamics because these sites were located in the same agro-climatic zone. Furthermore, these plantations were done almost at the same period. According to folklores, one defense person had introduced Santalum album at Jawala Mukhi (Personal Communication, 1989). Venkatesan et al. (1995) reported 4000 trees of sandalwood in Kangra valley near Jawala Mukhi of Himachal Pradesh.

The average maximum height and diameter growth at Site-I were found to be $15.50 \mathrm{~m}$ and $22.50 \mathrm{~cm}$, respectively. Whereas, at Site-II, these values were $14.25 \mathrm{~m}$ and $20.25 \mathrm{~cm}$. The maximum number of trees at Site-I were in diameter class up to $5-10 \mathrm{~cm}$ whereas, at Site-II maximum number of trees were in diameter class $<5 \mathrm{~cm}$. Very few trees have attained a harvestable diameter class i.e., $20-25 \mathrm{~cm}$.

The above findings indicate moderate tree growth although these are subjected to heavy biotic and abiotic interferences e.g., browsing by animals, heavy erosion of soils, and cutting/ lopping by local inhabitants. The heartwood oil content of trees was found to be $3.86 \%$ and $3.90 \%$ at Site-I and Site-II, respectively. It is comparable to the variations found in the trees growing in south India, the natural home of sandalwood. The specific physiochemical characteristics of soils and distinct ecological settings of the present sites bearing sandal stands in the North-Western Himalayas region may also have influenced the oil content. The difference between the minimum and maximum temperatures in Himachal Pradesh is much greater than in the southern states of India where there is a general tendency of temperature remaining around $20-30^{\circ} \mathrm{C}$. Temperature variations at the sites under study have been from $5-25^{\circ} \mathrm{C}$. This can also be a reason for variations in the oil content of sandalwood in Himachal Pradesh.

The phytosociological parameters i.e., density, percent frequency, basal area and importance value index (IVI) for the vegetation of sandal stand at Bilaspur and Jwala Mukhi have been tabulated in Table 2 and 3. Data tabulated in Table 2 reveals that the sandal forest at Bilaspur was dominated by Santalum album followed by Lannea coromandelica and Leucaena leucocephala with IVI 103.38, 31.50 and 29.09, respectively. Mallotus philippinensis and Bauhinia variegata have less distribution with IVI 8.77 and 5.42, respectively. Dalbergia sissoo, Albizia lebbeck and Caccia fistula had rare distribution with IVI 4.74, 4.74 and 3.93, respectively. Dominating shrubs were Carissa carandus and Lantana camara with IVI 30.97 and 29.89, respectively. Euphorbia
Table 2: Phytosociological parameters of vegetation in sandal stand at Bilaspur

\begin{tabular}{|c|c|c|c|c|}
\hline Name of species & $\begin{array}{c}\text { Den- } \\
\text { sity (No. } \\
\left.100 \mathrm{~m}^{-2}\right)\end{array}$ & $\begin{array}{l}\text { Fre- } \\
\text { quen- } \\
\text { cy (\%) }\end{array}$ & $\begin{array}{c}\text { Basal } \\
\text { area }\left(\mathrm{cm}^{2}\right. \\
\left.100 \mathrm{~m}^{-2}\right)\end{array}$ & IVI \\
\hline \multicolumn{5}{|l|}{ Trees } \\
\hline Santalum album & 17.60 & 100 & 784.09 & 103.38 \\
\hline $\begin{array}{l}\text { Lannea } \\
\text { coromandelica }\end{array}$ & 3.50 & 40 & 329.79 & 31.50 \\
\hline $\begin{array}{l}\text { Leucaena } \\
\text { leucocephala }\end{array}$ & 6.40 & 100 & 56.87 & 29.09 \\
\hline $\begin{array}{l}\text { Mallotus } \\
\text { philippinensis }\end{array}$ & 3.00 & 40 & 19.89 & 8.77 \\
\hline Bauhinia variegata & 2.00 & 20 & 29.74 & 5.42 \\
\hline Dalbergia sissoo & 1.00 & 20 & 25.72 & 4.74 \\
\hline Albizia lebbeck & 1.00 & 20 & 25.72 & 4.74 \\
\hline Cassia fistula & 1.00 & 20 & 14.47 & 3.93 \\
\hline \multicolumn{5}{|l|}{ Shrubs } \\
\hline Carissa carandus & 7.60 & 100 & 50.42 & 30.97 \\
\hline Lantana camara & 8.40 & 100 & 13.58 & 29.89 \\
\hline Euphorbia spp & 4.00 & 60 & 8.29 & 12.78 \\
\hline $\begin{array}{l}\text { Zizyphus } \\
\text { numularia }\end{array}$ & 2.33 & 60 & 10.79 & 11.01 \\
\hline Phoenis spp & 4.00 & 40 & 5.51 & 8.52 \\
\hline Dodonaea viscosa & 3.50 & 40 & 9.45 & 8.41 \\
\hline Agave americana & 2.00 & 20 & 2.91 & 3.49 \\
\hline Adhatoda vasica & 2.00 & 20 & 0.40 & 3.31 \\
\hline \multicolumn{5}{|l|}{ Grasses } \\
\hline $\begin{array}{l}\text { Chrysopogon } \\
\text { montanus }\end{array}$ & 40.00 & 60 & 5.35 & 186.04 \\
\hline $\begin{array}{l}\text { Dichanthium } \\
\text { anulatum }\end{array}$ & 32.70 & 20 & 4.20 & 113.96 \\
\hline
\end{tabular}

*Density and the basal area is on a per square meter basis

spp, Zizyphus numularia, Phoenix spp and Dodonaea viscosa were having an IVI of 12.78, 11.01, 8.52 and 8.41, respectively. Agave amerciana and Adhatoda vasica were rarely distributed with IVI 3.49 and 3.31, respectively. Dominating grass was Chrysopogon montanus with IVI 186.04 followed by Dicanthium anulatum with IVI 113.96. Data presented in Table 4 revealed that Santalum ablum was a dominating tree at Jawala Mukhi with IVI 87.51. The associated tree species were Acacia catechu and Dalbergia sissoo with an IVI of 21.92 and 21.35, respectively. Mallotus philippinensis showed a minimum IVI of 13.63. Dominating shrub was Lantana camara with IVI 51.99. It was followed by Adhatoda vasica, Carissa carandus, Murraya koenigii and Agave americana with IVI 24.14, 20.58, 18.92 and 15.47, respectively. Zizyphus 
Table 3: Phytosociological parameters of vegetation in sandal stand at Jawala Mukhi

\begin{tabular}{|c|c|c|c|c|}
\hline Name of species & $\begin{array}{c}\text { Density } \\
\text { (No. } 100 \\
m^{-2} \text { ) }\end{array}$ & $\begin{array}{c}\text { Fre- } \\
\text { quency } \\
(\%)\end{array}$ & $\begin{array}{c}\text { Basal } \\
\text { area }\left(\mathrm{cm}^{2}\right. \\
\left.100 \mathrm{~m}^{-2}\right)\end{array}$ & IVI \\
\hline \multicolumn{5}{|l|}{ Trees } \\
\hline Santalum album & 8.80 & 100 & 2050.32 & 87.51 \\
\hline Acacia catechu & 3.00 & 60 & 382.00 & 21.92 \\
\hline Dalbergia sissoo & 2.33 & 60 & 390.27 & 21.35 \\
\hline $\begin{array}{l}\text { Mallotus } \\
\text { philippinensis }\end{array}$ & 2.33 & 60 & 112.52 & 13.63 \\
\hline \multicolumn{5}{|l|}{ Shrubs } \\
\hline Lantana camara & 17.40 & 100 & 152.45 & 51.99 \\
\hline Adhatoda vasica & 12.67 & 60 & 42.62 & 24.14 \\
\hline Carissa carandus & 4.25 & 80 & 126.02 & 20.58 \\
\hline Murraya koenigii & 3.75 & 80 & 95.25 & 18.92 \\
\hline Agave Americana & 4.33 & 60 & 92.00 & 15.47 \\
\hline $\begin{array}{l}\text { Zizyphus } \\
\text { numularia }\end{array}$ & 2.00 & 60 & 63.20 & 11.86 \\
\hline $\begin{array}{l}\text { Dodonaea } \\
\text { viscosa }\end{array}$ & 2.00 & 60 & 44.36 & 11.33 \\
\hline \multicolumn{5}{|l|}{ Grasses } \\
\hline $\begin{array}{l}\text { Chrysopogon } \\
\text { montanus }\end{array}$ & 80.00 & 60 & 12.94 & 145.49 \\
\hline $\begin{array}{l}\text { Cymbopogon } \\
\text { martinii }\end{array}$ & 20.35 & 40 & 12.04 & 80.51 \\
\hline $\begin{array}{l}\text { Heteropogon } \\
\text { contortus }\end{array}$ & 25.00 & 40 & 8.52 & 74.00 \\
\hline
\end{tabular}

*Density and the basal area is on a per square meter basis

Table 4: Physio-chemical characteristics of soils

\begin{tabular}{|c|c|c|c|}
\hline $\begin{array}{l}\text { Sl. } \\
\text { No. }\end{array}$ & Parameter & $\begin{array}{c}\text { Site-I } \\
\text { (Bilaspur) }\end{array}$ & $\begin{array}{c}\text { Site-II } \\
\text { (Jawala Mukhi) }\end{array}$ \\
\hline
\end{tabular}

1. Soil Texture Sandy loam Silty loam

$\begin{array}{lll}\text { 2. Soil } \mathrm{pH} & 7.6 & 7.7\end{array}$

3. Organic carbon (\%) $\quad 1.72 \quad 0.70$

4. Nitrogen $\left(\mathrm{kg} \mathrm{ha}^{-1}\right) \quad 481.89 \quad 285.38$

5. Phosphorus $\left(\mathrm{kg} \mathrm{ha}^{-1}\right) \quad 13.39 \quad 12.27$

6. Potassium $\left(\mathrm{kg} \mathrm{ha}^{-1}\right) \quad 264.32 \quad 141.12$

numularia and Dodonaea viscosa showed lowest IVI of 11.86 and 11.33, respectively. Dominating grass was Chrysopogon montanus with IVI 145.49 followed by Cymbopogon martini and Heteropogon contortus with IVI 80.51 and 74.00, respectively.

Studies at both the sites revealed that Santalum album was the dominant species with Lannea coromandelica and Acacia catechu as co-dominants. Maximum IVI value for Sandal is attributed to its higher frequency, basal area and density. Carissa carandus and Lantana camara were dominant shrubs whereas, Chrysopogon montanus dominated the grass species.

At Site-I, Santalum album showed maximum dominance followed by Lannea coromandelica and Leucaena leucocephala. Maximum IVI for Santalum album is attributed to its higher frequency, basal area and density. Dalbergia sissoo, Albizia lebbeck and Cassia fistula have low dominance due to their low density, frequency and basal area. Among shrubs, Carissa carandus dominated the site, followed by Lantana camara. Agave Americana and Adhatoda vasica showed the least dominance. Chrysopogon montanus was found to be the most dominant grass at Site-I with an IVI Value of 186.04. It was due to its high frequency and basal area. The low distribution of Dicanthium anulatum (IVI 113.96) is attributed to its low frequency and basal area.

Data in Table 5 revealed that Santalum album dominated the vegetation at Site-II. Its IVI value was 87.51 . It was attributed to its higher frequency, basal area and density. Mallotus philippinensis had low dominance with IVI 13.63. The most dominant shrub at this site was Lantana camara (IVI 51.99). Zizyphus numularia and Dodonaea viscosa had got low dominance having IVI 11.86 and 11.33, respectively. Chrysopogon montanus (IVI 145.49) dominated the different grass species, owing to its high density, frequency and basal area. Heteropogon contortus (IVI 74.00) had the least density, frequency and basal area.

Data presented in Table 4 indicates that soil texture at Site-I (Bilaspur) and Site-II (Jawala Mukhi) was sandy loam and silty loam. The sandal is capable of growing in different kinds of soils like sand, clay, laterite, loam and black cotton soils (avoiding waterlogged conditions). Even very poor and rocky

Table 5: Leaf mineral nutrients content of Santalum album

\begin{tabular}{|c|c|c|c|c|c|}
\hline $\begin{array}{l}\text { Sl. } \\
\text { No. }\end{array}$ & Place & $\begin{array}{c}N \\
(\%)\end{array}$ & $\begin{array}{c}P \\
(\%)\end{array}$ & $\begin{array}{c}K \\
(\%)\end{array}$ & $\begin{array}{c}\mathrm{Ca} \\
(\%)\end{array}$ \\
\hline 1. & Bilaspur & 2.37 & 0.41 & 1.89 & 5.05 \\
\hline 2. & Jawala Mukhi & 2.38 & 0.43 & 2.59 & 5.63 \\
\hline
\end{tabular}

soils can support sandalwood (Rai, 1990). Whereas, soil pH at Site-I and Site -II was found to be 7.6 and 7.7, respectively. Organic carbon at Site-I and Site -II was found to be 1.72 and $0.70 \%$. Whereas, Nitrogen, phosphorus, and potassium at Site-I (Bilaspur) and Site-II (Jwala Mukhi) were found to be $481.89,13.39,264.32$ and $285.38,12.27,141.12 \mathrm{~kg} \mathrm{ha}^{-1}$, respectively.

Data on leaf mineral nutrients content of Santalum album trees growing at Site-I (Bilaspur) and Site-II (Jawala Mukhi) has been depicted in Table 5. N, P, K, Ca in the leaves of Santalum album trees growing at Site-I and Site-II were found to be 2.37, $0.41,1.89,5.05$, and $2.38,0.43,2.59,5.63 \%$, respectively. 


\section{Conclusion}

The present investigation concludes that a total of 1891 Sandalwood trees were found to be distributed at both the sites of Himachal Pradesh. Heartwood oil and leaf mineral nutrient contents were found maximum in the sandal trees growing at Jawala Mukhi in Kangra valley of Himachal Pradesh. Phytosociological studies revealed the dominance of Santalum album with Lannea coromandelica and Acacia catechu as codominant tree species. Carissa carandus and Lantana camara were the dominating shrubs, whereas, Chrysopogon montanus dominated the grass species.

\section{Acknowledgment}

The author expresses sincere thanks to Dr. Y.S. Parmar University of Horticulture and Forestry, Nauni, Solan for conducting research work on the Status of valuable tree Sandalwood (Santalum album Linn.) in low hills of Himachal Pradesh.

\section{References}

Anonymous, 1997. The secret of Satin Skin. Karnataka Soaps and Detergents Ltd. Bangalore 560055.

Chitra, P., Jijeesh, C.M., 2021. Biopriming of seeds with plant growth promoting bacteria Pseudomonas fluorescens for better germination and seedling vigour of the East Indian sandalwood. New Forests, 1-13.

Da Silva, J.A.T., Kher, M.M., Soner, D., Page, T., Zhang, X., Nataraj, M., Ma, G., 2016. Sandalwood: basic biology, tissue culture, and genetic transformation. Planta 4 , 847-887.

Doddabasawa, Chittapur, B.M., 2021. Sandalwood plantations - points to ponder 7. Current Science, 1184-1193.

Jackson, M.L., 1973. Soil chemical analysis. Prentice Hall of India, Pvt. Ltd., New Delhi, 498.

Merwin, H.D., Peech, M., 1951. Exchangeability of soil potassium in the sand, silt and clay fractions as influenced by the nature of the complementary exchangeable cation. In Soil Science American Proceedings 15, $125-128$.

Mishra, R., 1968. Ecology workbook -Oxford IBH Publishing Co. Calcutta, India, 244.

Nurochman, D., Matangaran, J.R., Santosa, G., Suharjito, D., Sari, R.K., 2019. Utilization system of sandalwood in aceh besar and Pidie districts. In IOP Conference Series: Earth and Environmental Science 394, 012046.

Olsen, S.R., 1954. Estimation of available phosphorus in soils by extraction with sodium bicarbonate (No. 939). US Department of Agriculture.

Piper, C.S., 1966. Soil and plant analysis. Hans Publishers, Bombay, India, 368.
Rai, S.N., 1990. Status and cultivation of Sandalwood in India. paper presented in the symposium on sandalwood in the pacific. Honolulu, Hawaii, 66-71.

Rao, P.S., Bapat, V.A., 1992. Micropropagation of sandalwood (Santalum album L.). In High-Tech and Micropropagation II. Springer, Berlin, Heidelberg, 193-210.

Rocha, D., Ashokan, P.K., Santhoshkumar, A.V., Anoop, E.V., Sureshkumar, P., 2014. Influence of host plant on the physiological attributes of field-grown sandal tree (Santalum album). Journal of Tropical Forest Science, 166-172.

Roy, S., Handique, G., Ahmed, R., Muraleedharan, N., 2017. Sandalwood oil (Santalum album L.): Source of a botanical pesticide-present status and potential prospects. Green Pesticides Handbook: Essential Oils for Pest Control, 217.

Sandeep, C., Manohara, T.N., 2019. Sandalwood in India: Historical and cultural significance of Santalum album L. as a basis for its conservation. NeBIO 10, 235-242.

Sandeep, C., Kumar, A., Rodrigues, V., Viswanath, S., Shukla, A.K., Sundaresan, V., 2020. Morpho-genetic divergence and population structure in Indian Santalum album L. Trees 34, 1113-1129.

Srinivasan, V.V., Sivaramakrishnan, V.R., Rangaswamy, C.R., Ananthapadmanabha, H.S., Shankaranarayana, K.H., 1992. Distrubution. Sandal (Santalum album Linn.), 7-11.

Subbiah, B.V., Asija, G.S., 1956. A rapid procedure for the estimation of available nitrogen in soil. Current Sciences 25, 259-260.

Sundararaj, R., Wilson, J.J., Vimala, D., 2019. Stem borers of Indian sandalwood (Santalum album Linn.) in Karnataka, India. Journal of the Indian Academy of Wood Science 16, 31-35.

Tah, J., 2021. Role of white sandal in times of COVID-19-A Hypothesis. Forward: The Pandemic Calls for More Colours Economies, 32.

Venkatesan, K.R., Srimathi, R.A., Kulkarni, H.D., 1995. Survey of sandal populations. Recent advances in research and management of sandal (Santalum album Linn) in India, 3-52.

Walkley, A., Black, T.A., 1934. An experimentations of the vegetative method for determining organic carbon and proposed modification of the chronic acid titration method. Soil Science 37, 38-39.

Xiao, Z., Bao, H., Jia, S., Bao, Y., Niu, Y., Kou, X., 2021. Organic hollow mesoporous silica as a promising sandalwood essential oil carrier. Molecules 26(9), 2744. 